\title{
CHANGES IN THE MICROBIAL COMPOSITION OF MUNICIPAL WASTEWATER TREATED IN BIOLOGICAL PROCESSES
}

\author{
Aleksandra Bawiec', Katarzyna Pawęska', Anna Jarząb² \\ 1 Wrocław University of Environmental and Life Sciences, Institute of Environmental Engineering, Grunwaldzki \\ Square 24, 50-363 Wrocław, Poland, e-mail: aleksandra.bawiec@up.wroc.pl, katarzyna.paweska@up.wroc.pl \\ 2 Ludwik Hirszfeld Institute of Immunology and Experimental Therapy, Polish Academy of Sciences, Weigla St. \\ 12, 53-114 Wrocław, Poland, e-mail: anna.jarzab@iitd.pan.wroc.pl
}

Received: 2016.02.15

Accepted: 2016.06.01

Published: 2016.07.01

\begin{abstract}
Municipal wastewater is characterized by diverse microbial content, largely dependent on their sources as well as many other factors like condition and health of their producer, but also environmental factors. The number and share of individual bacterial population in wastewater is changing during the process of their treatment in wastewater treatment plants. The microbial content of treated wastewater is significantly affected by the type of technology used for wastewater treatment. The paper presents the results of the species composition of bacteria present in the wastewater at various stages of treatment for the two different technologies. Samples of wastewater from hydroponic wastewater treatment plant and from the plant whose technology is based on biofilters were analysed. A key mechanism for wastewater treatment in both cases is biological treatment, using microbial activity that decomposes pollutants in the wastewater, which significantly contributes to changes in the species composition of bacteria comparing to microbiological composition of sewage flowing into the treatment plant. Analyses of microbial composition showed that in the objects consisting of preliminary tank and biofilter, composition of bacteria species is changing, but many species isolated from raw sewage is also found in treated wastewater. In the plant with hydroponic lagoon after wastewater treatment throughout the process system, bacteria present in raw sewage or in wastewater after biological treatment were not identified in the outlet.
\end{abstract}

Keywords: municipal wastewater, microbial composition, wastewater treatment

\section{INTRODUCTION}

The term "municipal wastewater" refers to a mixture of domestic and industrial sewage and runoff flowing into wastewater treatment plants that are responsible for treatment. As a medium consisting of water, organic substances (originated mainly from faeces and remains of food) and mineral substances, characterised by minimal temperature fluctuations, they provide a perfect environment for the development, existence and survival of fungi, viruses and bacteria, also including pathogenic organisms [Korzeniewska E., 2011]. The bacteriological composition of municipal wastewater depends on numerous factors, including, among others, the type of industrial facility discharging sewage to the common treatment plant (food processing plants, including slaughterhouses, are the main source of bacteria in inflowing sewage), the presence of hospitals and other public health facilities, the health condition of inhabitants as well as the quantity and quality of inflowing runoff but also the presence of animal breeding farms [Kim S., Aga D.S., 2007]. The diversity of microorganisms that exist in sewage may be subject to significant fluctuations as a result of changes occurring naturally in the environment and in the organisms that inhabit it. 
The factors that have the strongest influence on the quantity and type of bacteria include changes in population both of people and of animals, lifestyle changes, age, diseases or even trips to exotic countries [Rose C., Parker A. et al. 2015]. A vast majority of microorganisms in sewage are bacteria of the gastrointestinal tract that are excreted by humans and animals with faeces, including the Escherichia coli bacillus, faecal streptococcus Enterococcus faecalis and the Clostridium perfringens bacillus. It is estimated that faecal bacteria may account for as much as $25-54 \%$ of the content of faeces excreted by humans [Rose C., Parker A. et al. 2015]. Intestinal bacteria colonising their natural environment, i.e. the gastrointestinal tract, are responsible for its proper functioning by participating in the digestive process and in the synthesis of certain vitamins from the $\mathrm{B}, \mathrm{K}$ and $\mathrm{C}$ groups. Their pathogenic activity is manifested only if the bacteria are transferred to other parts of the body. What may be particularly dangerous in the presence of intestinal bacteria in the urinary tract, where they can cause a painful infection, as well as in the bile duct, lungs (hospital pneumonia) and the meninges (meningitis). These microorganisms may also be responsible for respiratory diseases, acute infections of the gastrointestinal tract, infections of wounds and cuts and the occurrence of endotoxin shock. Apart from their pathogenic activity, at high concentrations these bacteria have a toxic influence and may also cause allergies [Shuval H., 2003]. Depending on the health condition of the inhabitants or bred animals, the sewage may also contain such pathogenic bacteria as staphylococci (Staphylococcus aureus), streptococci (Streptococcus faecalis, Streptococcus pneumonice), Helicobacter pylori, Legionella pneumophilia or Salmonella spp [Yongabi K. A., 2010]. Apart from the pathogenic microorganisms, wastewater also contains toxic compounds released by the bacteria as a result of their physiological activity as well as due to the decomposition of dead bacterial cells (endotoxins, glucans, etc.) [Smit L. A. M., Spaan S., Heederik D., 2005]. It is worth noting that bacterial infections may be caused not only by coming into direct contact with sewage, e.g. as a result of lack of appropriate protective clothing and an injury, but also during the inhalation of aerosols generated in numerous sewage management facilities (activated sludge chambers, pumping stations or inspection wells). Pathogenic organisms or their spores may be carried with the aerosols on large distances and contaminate the surfaces where they have fallen. Endotoxins generated by gram-negative bacteria are particularly dangerous, as their quantity in the air surrounding wastewater treatment plants significantly exceeds the values that are safe for human health, depending on the technology used in the given plant, sampling site location or season of the year [Bauer H., Fuerhacker M. et al., 2002]. They often cause the occurrence of fever, breathing problems, hypoglycaemia, hypotension, leucocytosis or leucopoenia in wastewater treatment plant employees [Skowroń J., Golofit-Szymczak M., 2004]. Infectious diseases caused by viruses, bacteria, protozoa and helminths transmitted by water especially by water contaminated by raw but also treated wastewater are listed in Table 1.

Pathogenic bacteria are removed from sewage on all stages of treatment in the technological facility. A significant amount of bacteria (e.g. Salmonella, E. coli) is associated with easily falling suspension particles, so that they are removed from sewage as early as during the sedimentation process in primary settling tanks [Karim M. R. et al., 2004]. However, the most significant changes in the composition and quantity of microorganisms occur as a result of biological treatment with the use of activated sludge tanks or biological deposits, where organisms that create biofilms actively participate in the treatment process. Some genera of bacteria found in wastewater (ex. $B a$ cillus, Citrobacter, Pseudomonas) are responsible for organic carbon reduction [Ogugbue C.J., Ebode E.E., Leera S., 2015]. The reduction of the quantity of pathogenic bacteria results from antagonistic interactions between the pathogens and bacteria that develop in the depth of the wastewater as a result of adjustment of technological parameters of the treatment process. Organisms that play a major role here are protozoa inhabiting the biofilm of the activated sludge and feeding on the bacteria. These are mainly ciliates (Ciliata), including crawling ciliates (genus Aspidisca and Trachelopchyllum), free swimming ciliates (e.g. genus Litonotus, Euplotes, Colpidium, and Chilodonella) and sedentary ciliates (Vorticella Figure 1., Carchesium, Opercularia, Epistylis). [Papadimitriou Ch., Palaska G. et al., 2007]. Other important organisms that inhabit the activated sludge are tissue organisms such as nematodes (Figure 2) or rotifers, which, due to their high demand for energy, consume significant amounts of bacteria, thus reducing their quantity. 
Table 1. Infectious diseases transmitted by water [Poradnik Eksploatatora Oczyszczalni Ścieków 2011]

\begin{tabular}{|c|c|}
\hline Microorganisms & Diseases \\
\hline \multicolumn{2}{|c|}{ I.Viruses and enteroviruses } \\
\hline Hepatitis A & Hepatitis A virus (HAV) \\
\hline $\begin{array}{l}\text { ECHO } \\
\text { (Echovirus) }\end{array}$ & $\begin{array}{l}\text { infection of gastrointestinal tract, } \\
\text { aseptic meningitis, „colds” and } \\
\text { summer diarrhea of children, } \\
\text { hemorrhagic (bloody) conjunc- } \\
\text { tivitis }\end{array}$ \\
\hline $\begin{array}{l}\text { Coxackie } \\
\text { Coxsackievirus }\end{array}$ & $\begin{array}{l}\text { aseptic meningitis, respiratory } \\
\text { diseases, myocarditis }\end{array}$ \\
\hline $\begin{array}{l}\text { Polio } \\
\text { Picornaviridae }\end{array}$ & $\begin{array}{l}\text { infantile paralysis - poliomyelitis, } \\
\text { aseptic meningitis }\end{array}$ \\
\hline \multicolumn{2}{|l|}{ II. Bacteria } \\
\hline Shigella & bacillary dysentery \\
\hline Salmonella & $\begin{array}{l}\text { food poisoning, typhoid, } \\
\text { paratyphoid fever }\end{array}$ \\
\hline Vibrio cholerae & cholera \\
\hline Francisella tularenis & tularemia \\
\hline Bacillus anthracis & anthrax \\
\hline $\begin{array}{l}\text { Mycobacterium tubercu- } \\
\text { losis (tubercle bacilli) }\end{array}$ & tuberculosis \\
\hline Leptospirosis & $\begin{array}{l}\text { infectious jaundice, Weil's syn- } \\
\text { drome, jaundice and meningitis } \\
\text { symptoms }\end{array}$ \\
\hline Proteus & $\begin{array}{l}\text { urinary tract infection, pneumo- } \\
\text { nia, meningitis, food poisoning, } \\
\text { diarrhea }\end{array}$ \\
\hline \multicolumn{2}{|l|}{ III. Protozoa } \\
\hline Giardia Lamblia & $\begin{array}{l}\text { giardiasis (infection of the duo- } \\
\text { denal mucosa and intestines, } \\
\text { diarrhea) }\end{array}$ \\
\hline Entamoeba histolytica & $\begin{array}{l}\text { amoebic dysentery (bloody } \\
\text { diarrhea) }\end{array}$ \\
\hline Cryptosporidium & gastritis and enteritis, diarrhea \\
\hline \multicolumn{2}{|l|}{ IV. Helminths } \\
\hline $\begin{array}{l}\text { Trematodes (ciliated } \\
\text { larvae) }\end{array}$ & $\begin{array}{l}\text { bladder schistosomiasis with } \\
\text { haemorrhagic inflammation, } \\
\text { papilloma of bladder, bladder } \\
\text { fistula, bladder schistosomiasis } \\
\text { with quasi-dysentery inflamma- } \\
\text { tion, cirrhosis }\end{array}$ \\
\hline Human worm & $\begin{array}{l}\text { nausea, vomiting, insomnia, } \\
\text { pneumonia, leukocytosis, eosi- } \\
\text { nophilia }\end{array}$ \\
\hline
\end{tabular}

\section{MATERIALS AND METHODS}

The study presents the analyses of the microbial composition of municipal wastewater from two objects that use the biological treatment process: the wastewater treatment plant located in the motorway rest area, equipped with a tank with a submerged biofilter and a municipal sewage treatment plant that uses a hybrid circulationflow reactor and a hydroponic lagoon as the third stage of treatment.

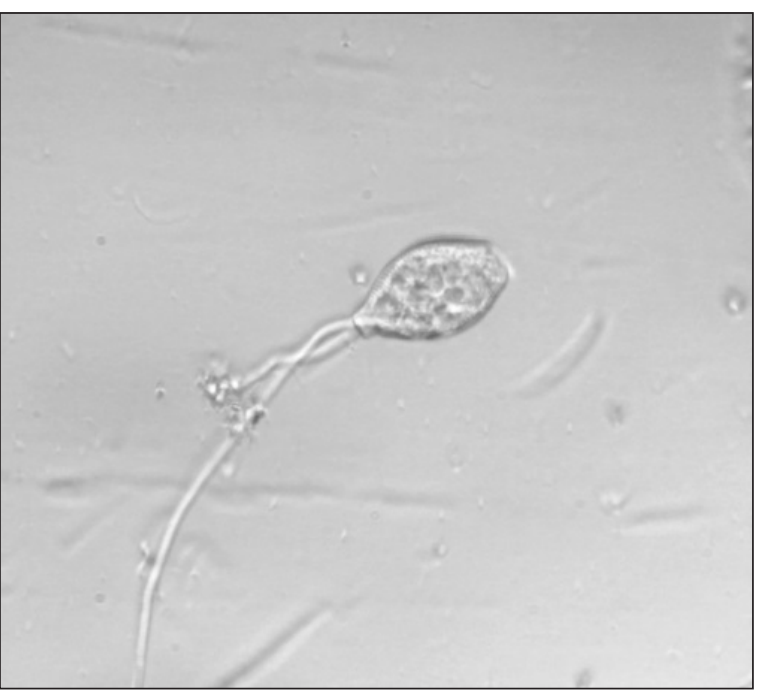

Figure 1. Ciliate from the genus Vorticella

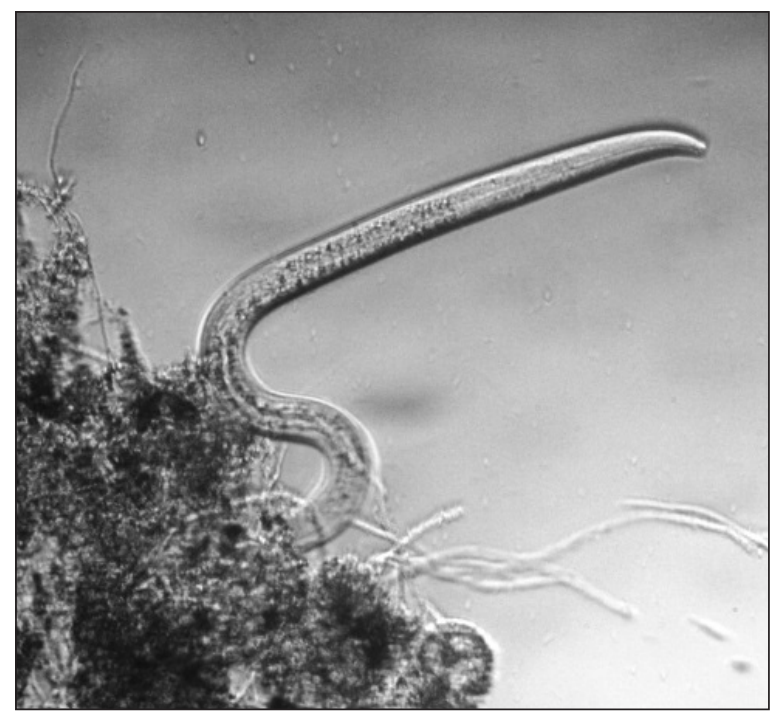

Figure 2. Nematode attached to the floc of activated sludge

The wastewater treatment plants in the rest area located in the Lower Silesian Voivodeship at the national motorway S8, designed for 50 resident equivalents, consist of a two-chamber septic tank and a chamber with submerged biofilter. In the septic tank suspensions are mechanically removed from sewage as a result of the sedimentation process (creation of sediments) and oils and grease are removed through the flotation process, (the emergence of scum). Mechanically treated sewage then flows to an aerated biofilter chamber. The reactor chamber contains a permanently fixed plastic filling, aerated from the bottom by a system of fine-bubble diffusors. Ensuring continuous aeration and a constant inflow of wastewater stimulates the development of biofilm in the reactor and determines the microbial composition 
of the flocs of activated sludge. Sewage flowing into the septic tank is characterised by an atypical composition, as it is only domestic sewage originating from toilets and lavatories and bus toilet sewage (no gastronomic activity is conducted in this rest area). Due to a significant share of urine, the sewage is characterised by increased concentrations of ammonium, which influence the resident microflora, and by a lack of biodegradable materials constituting a source of nutrients for bacteria.

The municipal wastewater treatment plant using a hydroponic lagoon as the third stage of sewage treatment (final treatment) of a capacity of 22396 RLM is located in the Opolskie Voivodeship. The designed capacity of the facility is 2500 $\mathrm{m}^{3} / \mathrm{d}$, although daily approx. $1350 \mathrm{~m}^{3}$ of sewage is supplied, as a mixture of domestic and industrial sewage and rainfall. In this object all technological processes (mechanical treatment, biological treatment, and final treatment) take place under roofing. Mechanical treatment is conducted with a use of screeners and a grit-chamber. After the removal of coarse fractions and a significant amount of suspensions, the sewage is directed to a circulation, self-controlling hybrid reactor, where two types of biological treatment are used: treatment with the use of settled biomass on submerged plastic panels and flocks of activated sludge flowing freely in the depth of the sewage. As the reactor is divided into oxygenated and anoxic zones, nitrification and denitrification processes, carried out with the use of specially cultivated strains of bacteria, occur alternately. The type of bacteria developing in the sewage is influenced by the quality of sewage supplied to the reactor, the intensity of aeration in oxygenated chambers and wastewater retention time before it is directed to the secondary sedimentation tank. Subsequent stages of the biological treatment process take place in the hydroponic lagoon designed to resemble an artificial river, where species of macrophyte plants are planted on plastic pillars to support the process of removal of nitrogen and phosphorus from the sewage. The flow of wastewater through the lagoon channel may lead not only to changes in the physical and chemical composition of sewage as the nutrients are assimilated by plants, but also to changes in the microbial composition as a result of the influence of the specific bacterial flora that develops on the roots of macrophytes (in the rhizosphere).
Microbiological analyses of wastewater samples were performed at the Institute of Immunology and Experimental Therapy in Wroclaw. 100 $\mu 1$ samples of sewage, 100 times diluted, originating from subsequent treatment stages in the analysed objects, were sown on nutrient agar plates and incubated during the night at $37{ }^{\circ} \mathrm{C}$. Colonies that have grown after 24 hours of cultivation were identified basing on the protein profile of specific strains with use of the MALDI-Biotyper technique. In order to do so, microorganism cells were suspended in $70 \%$ ethanol, then the cell pellet was agitated at $10000 \mathrm{x}$ g for $2 \mathrm{~min}$, dried and proteins were extracted with the use of a mixture of formic acid and acetonitrile in the proportion of 1:2.

After extraction, $1 \mu \mathrm{l}$ of the suspension was placed on a steel plate MSP 48 Polished Steel Target and air-dried. After drying the suspension of bacterial proteins, the plate was covered with a matrix solution of HCCA ( $\alpha$-cyano-4hydroxycinnamic acid), air-dried and analysed with the use of a mass spectrometer MALDITOF-MS (Matrix Assisted Laser Desorption Ionization-Time of Flight) (Bruker, Germany). Individual species were identified with use of MALDI Biotyper software (Bruker, Germany).

\section{RESULTS AND DISCUSSION}

The bacteria identified in raw and treated sewage originating from treatment plants in motorway rest area and from the two step wastewater treatment plant with hydroponic lagoon are listed in Tables 2 and 3.

The occurrence of colonies of bacteria cultivated on nutrient, originating from specific sample collection sites (raw sewage and hydroponic lagoon) is shown in Figure 3.

\section{CONCLUSIONS}

Apart from maintaining high efficiency in the removal of pollutants dissolved in wastewater, another important factor in the treatment process is to provide a stable sanitary composition of sewage introduced to collectors (soil, surface waters). A majority of the microflora present both in raw wastewater and in the sewage discharged to the collector are microorganisms that inhabit the gastrointestinal tract 
Table 2. Identification of bacteria species isolated from wastewater before and after treatment processes in Rest Area

\begin{tabular}{|c|c|c|}
\hline Rest Area & Species isolated in untreated wastewater & Species isolated in treated wastewater \\
\hline Rest Area 1 & $\begin{array}{l}\text { Klebsiella pneumoniae* } \\
\text { Escherichia coli** } \\
\text { Aeromonas hydrophila* }\end{array}$ & $\begin{array}{l}\text { Aeromonas hydrophila* } \\
\text { Citrobacter freundii* } \\
\text { Citrobacter braakii }\end{array}$ \\
\hline Rest Area 2 & $\begin{array}{l}\text { Staphylococcus aureus } \\
\text { Alcaligenes feacalis } \\
\text { Escherichia coli** } \\
\text { Klebsiella pneumoniae* }\end{array}$ & $\begin{array}{l}\text { Aeromonas caviae* } \\
\text { Aeromonas hydrophila* } \\
\text { Serratia marcescens }\end{array}$ \\
\hline Rest Area 3 & $\begin{array}{l}\text { Pseudomonas luteola** } \\
\text { Bacillus macenensis }\end{array}$ & $\begin{array}{l}\text { Aeromonas hydrophila* } \\
\text { Camamonas nitrativorens }\end{array}$ \\
\hline Rest Area 4 & $\begin{array}{l}\text { Camamonas nitrativorens } \\
\text { Aeromonas hydrophila* } \\
\text { Providencia rettgeri** }^{*}\end{array}$ & 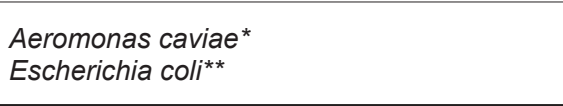 \\
\hline
\end{tabular}

* pathogenic species that threaten human or aquatic organisms

** potentially pathogenic species

A

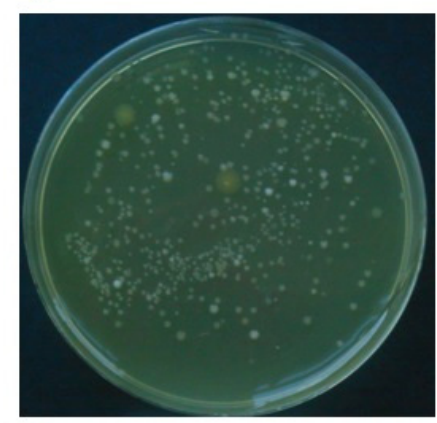

D

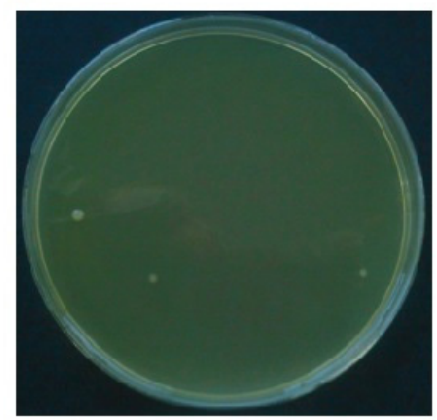

B

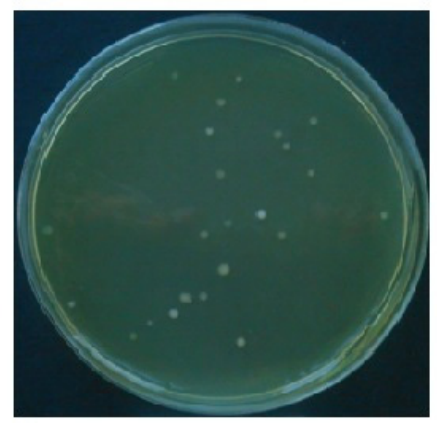

E

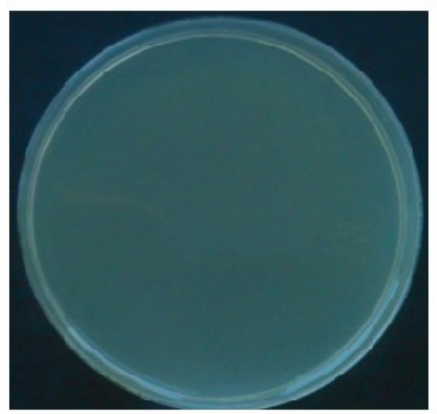

C

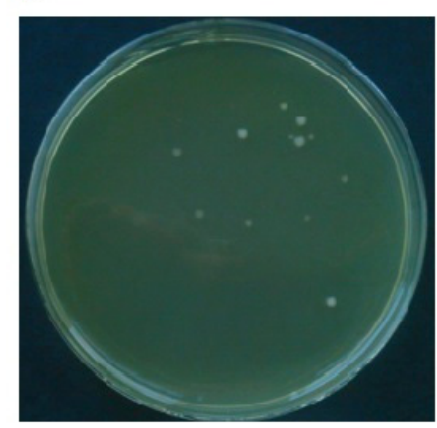

Figure 3. Microorganisms cultured from $100 \mathrm{ml}$ of wastewater (100-times dilution), from different phase of wastewater treatment; $\mathrm{A}$ - untreated wastewater, $\mathrm{B}$ - the inlet to the hydroponic lagoon, $\mathrm{C}$ - the hydroponic lagoon $1, \mathrm{D}$ - the hydroponic lagoon $2, \mathrm{E}$ - the outlet from wastewater treatment plant

of humans and animals. However, wastewater may also contain pathogenic organisms that may constitute a threat both for the environment and for human health. In spite of high efficiency of the removal of bacteria during wastewater treatment processes (over 99\%), $10^{4}$ to $10^{6}$ faecal-type E.coli bacteria are still observed on the outflow [Quant B. et al.]. The quantity of microorganisms considered harmful or dangerous is closely linked to the applied technology of treatment.
In Poland there is no unconditional obligation to disinfect sewage. Only such facilities as hospitals, clinics or laboratories have to demonstrate that they use additional wastewater treatment methods, including disinfection.

One of few documents that refer to the sanitary quality of outflows from wastewater treatment plants is the Regulation of the Minister of Health of April 8, 2011 on the supervision of water quality in bathing areas or areas used for bathing (Journal of Laws, 2011.86.478). Unfortu- 
Table 3. Identification of bacteria species isolated from wastewater at different stage of the two-step hydroponic sewage treatment plant

\begin{tabular}{|c|c|}
\hline $\begin{array}{c}\text { Phase of wastewater } \\
\text { treatment }\end{array}$ & Isolated species \\
\hline Untreated wastewater & $\begin{array}{l}\text { Analysis of random selected } \\
\text { colonies species: } \\
\text { Proteus mirabilit } \\
\text { Enterobacter cloacae } \\
\text { Escherichia coli } \\
\text { Klebsiella pneumoniae } \\
\text { Citrobacter freundii } \\
\end{array}$ \\
\hline $\begin{array}{l}\text { The inlet to the hydro- } \\
\text { ponic lagoon (waste- } \\
\text { water after biological } \\
\text { treatment) }\end{array}$ & $\begin{array}{l}\text { Escherichia coli } \\
\text { Morganella morgani } \\
\text { Enterobacter asburiae } \\
\text { Enterobacter cloacae } \\
\text { Citrobacter braakii } \\
\text { Citrobacter freundii } \\
\text { Citrobacter koseri } \\
\text { Klebsiella oxytoca } \\
\text { Kleebsiella pneumonia } \\
\text { Enterococcus faecalis } \\
\text { Enterococcus faecium } \\
\text { Bacillus pumilus }\end{array}$ \\
\hline The hydroponic lagoon 1 & $\begin{array}{l}\text { Klebsiella pneumoniae } \\
\text { Klebsiella oxytoca } \\
\text { Enterobacter cloacae } \\
\text { Escherichia coli } \\
\text { Citrobacter freundii } \\
\text { Citrobacter braaki } \\
\text { Raoultella planticola } \\
\text { Acinetobacter pittii } \\
\text { Acinetobacter } \\
\text { Morganella morgani } \\
\text { Raoultella ornithinolytica } \\
\text { Staphylococcus haemolyticus }\end{array}$ \\
\hline The hydroponic lagoon 2 & $\begin{array}{l}\text { Raoultella planticola } \\
\text { Escherichia coli }\end{array}$ \\
\hline $\begin{array}{l}\text { The outlet from wastewa- } \\
\text { ter treatment plant }\end{array}$ & Lack of isolated species \\
\hline
\end{tabular}

nately, it does not foresee an unambiguous obligation to disinfect wastewater each time before it is introduced into the environment.

\section{REFERENCES}

1. Bauer H., Fuerhacker M., Zibuschka F., Schmid H., Puxbaum H., 2002. Bacteria and fungi in aerosols generated by two different types of wastewater treatment plants, Water Research, Volume 36, Issue 16, 3965-3970.

2. Budzińska K. et al. 2013. Wpływ procesów oczyszczania ścieków w technologii SBR na stan sanitarny powietrza atmosferycznego. Rocznik Ochrony Środowiska, vol. 15, 904-923.

3. Dymaczewski Z. (Ed.) 2011. Poradnik eksploa- tatora oczyszczalni ścieków. Polskie Zrzeszenie Inżynierów i Techników Sanitarnych Oddział Wielkopolski, Poznań.

4. Karim M.R., Manshadi F.D., Karpiscak M.M., Gerba C.P., 2004. The presistence and removal of enteric pathogens in constructed wetlands, Water Research 38, 1831-1837.

5. Kim S., Aga D.S., 2007. Potential Ecological and Human Health Impacts of Antibiotics and Antibiotic-Resistant Bacteria from Wastewater Treatment Plants, Journal of Toxicology and Environmental Health, Part B, 559-573.

6. Korzeniewska E., 2011. Emission of bacteria and fungi in the air from wastewater treatment plants $-\mathrm{a}$ review, Frontiers in Bioscience, Jan 1; 3, 393-407.

7. Ogugbue C.J., Ebode E.E., Leera S., 2015. Electricity generation from swine wastewater using microbial fuel cell. J. Ecol. Eng., 16(5), 26-33.

8. Quant B., Bray R., Olańczuk-Neyman K., Jankowska K., Kulbat E., Łuczkiewicz A., Sokołowska A., Fudala S., 2009. Badania nad dezynfekcją ścieków oczyszczonych odprowadzanych do wód powierzchniowych, Monografie Komitetu Inżynierii Środowiska Polskiej Akademii Nauk vol. 61, III Kongres Inżynierii Środowiska tom 4, 19-29.

9. Papadimitriou Ch., Palaska G., Lazaridou M., Samaras P., Sakellaropoulos G. P., 2007. The effects of toxic substances on the activated sludge microfauna, Desalination, 211(1-3), 10, 177-191.

10. Rose C., Parker A., Jefferson B., Cartmell E., 2015. The Characterization of Feces and Urine: A Review of the Literature to Inform Advanced Treatment Technology, Critical Review in Environmental Science and Technology, Sep 2, 45(17), 1827-1879.

11. Shuval H., 2003. Estimating the global burden of thalassogenic diseases: human infectious diseases caused by wastewater pollution of the marine environment, Journal of Water and Health, 01.2, 53-64.

12. Skowroń J., Gołofit-Szymczak M., Zanieczyszczenie mikrobiologiczne powietrza w środowisku pracy - źródło, rodzaje i oznaczanie, Bromatologia i Chemia Toksykologiczna, 37(1), 91-98.

13. Smit L.A M., Spaan S., Heederik D., 2005. Endotoxin exposure and symptoms in wastewater treatment workers, American Journal of Industrial Medicine 48, 30-39.

14. Yongabi K.A., 2010. Biocoagulants for Water and Waste Water Purification: a Review, International Review of Chemical Engineering, 2(3), 444-458. 